\title{
PERILAKU LIMINAL MASYARAKAT SASAK-LOMBOK DALAM BÊKAYAQ BAU NYALÉ DAN PATAQ PARÉ
}

\author{
Saharudin $^{1}$
}

\begin{abstract}
This paper studied the socio-psychological issues found in the cultural event bêkayaq bau nyalé and bêkayaq pataq paré among Sasak agrarian society in the southern of the Lombok Island. The study examined the language used in the two types of bêkayaqs (reverberate poem activities) used an ethnopoetic perspective. The socio-psychological problems of the people were revealed and explained by an ethnohermeneutic and process analysis perspectives. Data were collected by observation and interview techniques. The results showed that the tradition of bêkayaq bau nyalé and pataq paré were not only verbal-artistic expressions, but also had a deep implication for the disclosure of the socio-cultural pressures of the culprit during their life in which they had to obey the obligations of the social and cultural normative structures. Through bêkayaq, they could remove their burdens (though it was only temporal). The main purpose of bêkayaq was to create a liminal world between women and men, at least in public area communication. The changes in the orientation of bau nyale, the inclusion of structural context (power), and the rationalization of rice farming, had an impact on people's behavior changes to the actors of bêkayaq.
\end{abstract}

Keywords: bêkayaq, behavioral culture, male-female interaction, liminality, behavioral changes.

\section{Pendahuluan}

Bahasa mengekspresikan realitas sosial-budaya sekaligus merupakan penjelmaan realitas sosial-budaya. Tradisi bêkayaq bau nyale dan pataq pare, adalah sebuah contoh dari realitas sosial-budaya masyarakat Sasak agraris, dimana bahasa menjadi media dalam mengekspresikannya. Bêkayaq, adalah aktivitas berbalas pantun yang dilagukan dalam masyarakat Sasak-Lombok agraris (di bagian selatan pulau Lombok) yang dilakukan dalam konteks dan tujuan tertentu. Diantaranya adalah bêkayaq dalam kegiatan menangkap nyale (bau nyale) di pantai dan mengetam padi (pataq pare) di sawah. Tradisi bau nyale ini tidak diketahui secara pasti kapan

\footnotetext{
${ }^{1}$ Dosen UPT MKU Universitas Mataram, Mataram 83125, Indonesia dan Mahasiswa S-3 Ilmu-Ilmu Humaniora Universitas Gadjah Mada, Yogyakarta 55281, Indonesia. E-mail: sahrul_saharuddin@yahoo.com
} 
mulai ada dalam budaya orang Sasak agraris. Salah satu jejak yang bisa diketahui hanya tentang cerita kejadian nyale (Palola paridis L.), yang berawal dari kisah tragis dan romantis seorang putri raja yang bernama Putri Mandalika. Dalam versi yang lain, nyale berasal dari jelmaan sorban Nabi Adam yang jatuh di tepi pantai. Dalam konteks mitos asal-muasal nyale versi Putri Mandalika, kisahnya (secara nirsadar) melambangkan kontradiksi-kontradiksi strata sosial, budaya, dan kekuasaan, yang secara empiris dialami masyarakat pendukung tradisi bau nyale itu pada waktu dahulu.

Meskipun tradisi bau nyale berlangsung di pantai-laut dan pataq pare di sawahdarat, menariknya kedua aktivitas tersebut (dahulunya) sama-sama menggunakan bêkayaq sebagai salah satu budaya perilaku yang memediasi komunikasi selama pelaksanaannya. Tidak hanya itu, nyale yang diyakini (oleh sebagian orang) sebagai jelmaan Putri Mandalika itu, juga digunakan sebagai obat (sêreat atau sarat) untuk kesuburan padi. Sepulang dari tempat penangkapan nyale, para petani mencuci semua bekas peralatan menangkap nyale di sawah dengan harapan sisa-sisa nyale membawa khasiat bagi kesuburan padi. Dari sini terlihat ada korelasi antara nyale dengan padi, antara laut (ruang praliminal) dengan darat (ruang post-liminal) yang dihubungkan oleh pantai sebagai ruang liminal.

Lebih lanjut, masyarakat Sasak (terutama para petani di bagian selatan pulau Lombok) sangat aktif dalam setiap pelaksanaan bau nyale. Ini tampaknya tidak lepas dari ruang bebas dan ekspresi yang disediakan dalam tradisi ini, terutama ruang interaksi antara kaum muda-mudi Sasak. Mengingat pola relasi antara muda-mudi di kalangan masyarakat Sasak pada zaman dahulu (terutama sebelum tahun 2000an) sangat ketat, patuh pada kewajiban-kewajiban sosial, dan taat dalam budaya patrilinial (Yasin, 2008; Zuhdi, 2012; Smith, 2014). Kaum wanita (terutama para gadis) harus bisa menjadi "penjaga kebun" kehormatan keluarga sehingga ruang bebas bagi mereka sangat dibatasi. Dalam hal interaksi muda-mudi di ruang domestik (di rumah atau bêrugaq), khususnya saat midang 'semacam perkenalan/berpacaran' persoalan atau hal-hal yang berbau seksual sangat dijaga. Sebaliknya, di lokasi bau nyale konotasi yang berbau seksual sering dilontarkan oleh pria. ${ }^{2}$ Dengan demikian, hubungan sosial mereka di rumah lebih private dan secret, sedangkan di lokasi bau nyale lebih terbuka dan umum (open dan public).

\footnotetext{
${ }^{2}$ Pada saat malam atau menjelang subuh saat turun ke tepi pantai untuk menangkap nyale, para pria sering berteriak di dekat kerumunan wanita dengan mengatakan: "jabuuut, jabuuut, jabuuut" hingga berkali-kali, lalu beberapa laki-laki menimpali ucapan yang sama atau menjawab: "jabuuuut nyale" hingga berulang-ulang. Kata "jabut" di sini konotasinya adalah
} 
Bagi kaum muda-mudi masyarakat Sasak Lombok, datangnya musim bau nyale semacam harapan untuk "bebas" dari beragam kewajiban sosial-budaya tersebut. Tidak heran jika kemudian pemuda-pemudi berduyun-duyun pergi ke tempat penangkapan nyale sambil menginap di bawah tenda mereka masing-masing. Untuk mengisi waktu lowong dan melepas kekakuan hubungan antara muda-mudi ini maka diciptakan semacam media interaksi atau dunia sosial diantara mereka melalui kegiatan bêkayaq (betandaq-dalam dialek bahasa Sasak yang lain). Kegiatan bêkayaq bisa berlangsung berjam-jam antara kelompok pemuda dan pemudi dari beda kampung yang sudah saling kenal ataupun belum. Tidak hanya itu, jika mereka bersepakat, kaum pria yang biasanya kalah dalam adu kayaq ini, mereka akan datang menebus barang-barang (seperti kain tenun) yang menjadi taruhannya. Di samping itu, pria yang merasa cocok dengan gadis/janda dari kelompok bêkayaq tersebut akan datang pada musim panen padi (pataq pare). Pada saat panen padi inilah terjadi lagi "pertarungan" antarkelompok pria dan wanita dalam mengadu kayaq guna mengekspresikan perasaannya. Jika mereka merasa cocok setelah berkenalan (terutama yang baru bertemu pertama kali di tempat penangkapan nyale), hubungan mereka pun berlanjut sehingga kemungkinan besar selesai panen padi mereka akan menikah. Sebaliknya, jika tidak cocok mereka akan berteman saja. Fenomena bêkayaq di kalangan masyarakat Sasak agraris ini hampir sama dengan yang terjadi di kalangan komunitas Marapu Wanokaka, Lamboya, dan Kodi di pulau Sumba, Nusa Tenggara Timur, khususnya saat menangkap nyale (Daeng, 2008: 116-129).

Memperhatikan fenomena sosial-budaya tersebut, muncul pertanyaan: apakah tradisi bêkayaq bau nyale dan pataq pare dalam masyarakat Sasak agraris hanya sebatas ekspresi emosional-artistik, ataukah ada motif lain di balik itu? Di samping itu, jika memperhatikan aktor-aktor yang terlibat dalam bêkayaq bau nyale dan pataq pare, patut dipertanyakan, mengapa ekspresi kebahasaan mereka cenderung menggunakan "ritualisasi bahasa"? Apakah ini berkaitan dengan relasi antarkaum muda-mudi yang selama ini "terkekang" dalam struktur sosial-budaya masyarakat setempat? Ataukah ini adalah representasi dan penyatuan dari kecenderungan mereka yang ingin mengartikulasikan diri (cf. Barker, 2014) pada ruang bebas lewat media bahasa berwujud kayaq?

bulu kemaluan wanita, namun dipelesetkan dengan menyambung kata "jabut" tersebut dengan kata nyale. Kata-kata tersebut termasuk tabu diucapkan, tetapi selama di lokasi bau nyale seolah-olah tidak ditabukan. 
Gejala sosial-budaya ini menarik dikaji dengan melibatkan perspektif pelaku (emik, pihak yang diteliti). Fenomena sosial-budaya dalam masyarakat Sasak agraris tersebut adalah sesuatu yang telah disadari. Oleh karena itu, pemerian tentang gejala tersebut tidak lain merupakan deskripsi mengenai apa yang ada di sekeliling mereka (Ahimsa-Putra, 2005; 2009). Dalam konteks ini adalah persoalan perubahan perilaku antara kaum muda-mudi (pria dan wanita) Sasak-Lombok di ruang publik. Untuk masuk ke persoalan tersebut akan ditelaah terlebih dahulu lewat bahasa kayaq yang menjadi media artikulasinya dan peristiwa sosial-budaya yang menyertainya. Hal ini didasari oleh pandangan bahwa bahasa merupakan alat untuk membangun realitas sosial dan sarana untuk mengkomunikasikan kenyataan-kenyataan sosial serta makna-makna yang dimiliki oleh para pelaku yang terlibat dalam suatu interaksi (Phillipson, 1972 dalam Ahimsa-Putra, 1985).

Berdasarkan pada deskripsi awal tentang peristiwa sosial-budaya berupa tradisi bêkayaq dalam bau nyale dan pataq pare di kalangan masyarakat Sasak (agraris) di atas, tulisan ini mencoba mendiskusikan tentang implikasi sosial-psikologis peristiwa budaya yang bernama bêkayaq bau nyale dan pataq pare bagi pelaku budaya tersebut (masyarakat Sasak-Lombok di bagian selatan). Analisis terutama dilakukan pada peristiwa bêkayaq yang sangat dominan dalam memperlihatkan interaksi sosial antarkaum pria dan wanita (muda-mudi). Interaksi sosial dalam konteks tulisan ini dimaknai sebagai hubungan yang terbangun lewat adanya proses yang bersifat asosiatif seperti kerjasama dan akomodasi. Dengan demikian, interaksi sosial dipahami sebagai suatu tatanan yang dirembukkan secara temporer, bahkan muncul sebagai hasil konstruksi sosial (cf. Soekanto, 2005; Coulon, 2003).

\section{Metode Penelitian}

Penelitian ini dapat dipilah menjadi dua bagian. Pertama, mencari representasi formula kebahasaan bêkayaq bau nyale dan pataq pare itu sendiri sebagai sebuah gejala sosial-budaya dalam mewadahi tingkah laku sosial dan kondisi psikologis penuturnya. Hal yang dilakukan di sini adalah mengidentifikasi dan mendeskripsikan sisi kebahasaan dan tradisi bêkayaq bau nyale dan pataq pare. Juga, hal-hal yang berkenaan dengan skemata sosial-budaya bêkayaq pada dua jenis aktivitas masyarakat Sasak-Lombok tersebut. Ini dilakukan untuk mengetahui faktor-faktor sosial dan psikologis yang mendorong masyarakat pelakunya mengubah atau tidak mengubah perilaku sosialnya selama kegiatan bau nyale dan pataq pare itu berlangsung. Kedua, menjelaskan orientasi perubahan perilaku 
masyarakat pelaku bêkayaq bau nyale dan pataq pare sendiri sesuai yang tercermin melalui perilaku verbal (buaq kayaq 'bait pantun') dan non-verbal selama aktivitas tersebut berlangsung. Di samping itu, akan dijelaskan pula pola-pola interaksi sosial masyarakat Sasak-Lombok pelaku/pendukung bêkayaq bau nyale dan pataq pare tersebut.

Adapun teknik pengumpulan data yang digunakan adalah teknik pengamatan (terutama untuk mengumpulkan data terkait human behavior-nya) dengan posisi observer-as-participant. Peneliti melakukan pengamatan dan wawancara terstruktur dan non-terstruktur dalam kunjungan yang dilakukan secara bertahap. Sementara itu, penelitian ini dilakukan di satu wilayah pemukiman, yakni Batu Nampar, dan dua lokasi tempat berlangsungnya peristiwa bau nyale, yakni pantai Sungkun (Ekas Buana) dan Kaliantan (Seriwe) di Kecamatan Jerowaru, Kabupaten Lombok Timur. Pemilihan lokasi didasarkan pada pertimbangan bahwa (a) wilayah pemukiman Batu Nampar memiliki penduduk yang masih aktif pergi menangkap nyale dan tempat masih banyaknya ditemukan mantan pelaku bêkayaq bau nyale dan pataq pare; dan (b) pantai Sungkun serta Kaliantan (bukan di pantai Seger, Kuta, Lombok Tengah sebagai lokasi lain bau nyale) merupakan lokasi penangkapan nyale dan lokus kegiatan bêkayaq bau nyale khusus untuk masyarakat wilayah Jerowaru dan sekitarnya. Persamaan lokasi (kecamatan) ini diasumsikan memiliki implikasi terhadap kedekatan orientasi kegiatan bêkayaq bau nyale dan pataq pare. Hal ini memiliki relasi dengan sejauh mana perubahan sosial yang diharapkan mampu merubah atau mempertahankan pola-pola interaksi sosial masyarakat setempat, khususnya interaksi sosial kaum pria dan wanita di ruang publik.

Perlu dikemukakan bahwa data yang terkait bêkayaq pada saat peristiwa pataq pare untuk saat ini sudah sulit ditemukan konteks peristiwanya. Masyarakat setempat dalam memanen padi sudah tidak lagi menggunakan sistem lama, yakni dengan memotong tangkai padi dengan ani-ani (rangkap), terutama untuk jenis/varietas padi lokal. Akibatnya, tradisi bêkayaq pataq pare telah hilang. Oleh karena itu, yang mungkin dilakukan untuk memperoleh buaq kayaq saat pataq pare adalah penggalian informasi melalui wawancara serta dialog dengan para pelaku yang masih hidup dan pernah melakukan kegiatan bêkayaq saat panen padi pada waktu dulu. Dari bahan pustaka, pengambilan data tentang buaq kayaq bau nyale diambil sebagian dari tulisan Ecklund (1977).

Selanjutnya, data yang dianalisis dalam tulisan ini berupa bahasa berwujud tuturan yakni pantun (Sasak: kayaq/lêlakaq) yang dilantunkan antarmuda-mudi (kelompok pria dan wanita) saat mereka saling menimpali atau berbalas kayaq pada 
acara bau nyale dan pataq pare. Jadi, subyek penelitian ini adalah masyarakat penutur dan pelaku bêkayaq itu. Dipilihnya data bahasa sebagai pintu masuk untuk melihat bagaimana gambaran psikologis mereka karena diyakni bahwa bahasa verballah yang dapat mengekspresikan kondisi psikologis penuturnya atau cenderung sebagai bentuk pikirannya (lihat Mahyuni, 2004). Bahkan, menurut Mahyuni (2007) bahasa tak terpisahkan dari budaya, yang merupakan warisan sosial berwujud paduan tindakan dan kepercayaan yang menentukan tekstur kehidupan kita. Selain itu, data yang dijadikan pendukung bahan analisis adalah peristiwa budaya yang terkait dengan acara bau nyale dan pataq pare.

\section{Tabel 1. Metode Penelitian}

\begin{tabular}{|c|c|c|c|c|}
\hline Teknik & Tujuan & $\begin{array}{l}\text { Research } \\
\text { Questions }\end{array}$ & Subyek & $\begin{array}{c}\text { Penggalian } \\
\text { Informasi }\end{array}$ \\
\hline $\begin{array}{l}\text { Observer-as- } \\
\text { participant }\end{array}$ & $\begin{array}{l}\text { - Deskripsi } \\
\text { - Eksplanas } \\
\text { i }\end{array}$ & $\begin{array}{l}\text { - Bagaimana } \\
\text { representasi } \\
\text { kebahasaan bêkayaq } \\
\text { bau nyale dan pataq } \\
\text { pare dengan kondisi } \\
\text { sosial-psikologis } \\
\text { masyarakat } \\
\text { pelakunya? } \\
\text { - Bagaimana orientasi } \\
\text { perubahan perilaku } \\
\text { masyarakat pelaku } \\
\text { bêkayaq bau nyale dan } \\
\text { pataq pare melalui } \\
\text { representasi } \\
\text { kebahasaan serta } \\
\text { pola interaksi } \\
\text { sosialnya? }\end{array}$ & $\begin{array}{l}\text { Masyarakat } \\
\text { pelaku bêkayaq } \\
\text { bau nyale dan } \\
\text { pataq pare } \\
\text { - Batu Nampar } \\
\text { - Sungkun dan } \\
\text { Kaliantan }\end{array}$ & $\begin{array}{l}\text { - Kunjungan } \\
\text { bertahap } \\
>\text { Wawancara } \\
\text { (informan } \\
\text { kunci dan } \\
\text { pendukung) }\end{array}$ \\
\hline
\end{tabular}

Data yang sudah diperoleh dengan metode di atas, dianalisis dengan menganalisis segi kebahasaan kayaq sebagai teks dengan ciri khas kelokalannya, yang dalam konteks ini memanfaatkan perspektif etnopuitik-etnohermeneutik. Kemudian, berfokus pada pengetahuan lokal, yakni kearifan lokal yang menjelaskan maknasosial dari bêkayaq tersebut bagi masyarakat setempat guna menemukan persoalanpersoalan sosial-psikologis yang melatari dan menjadi arah artikulasi dilakukan bêkayaq itu sendiri. Model analisis etnohermeneutik (dalam tulisan ini) dipahami 
sebagai metode analisis yang didasarkan pada pandangan/pengetahuan emik dan pandangan etik (cf. Kadarisman, 2010; Geertz, 2003)

\section{Bau Nyale dan Pataq Pare: Gambaran Tradisi Laut dan Tradisi Darat}

Tradisi Bau Nyale atau menangkap nyale adalah salah satu tradisi yang masih tetap dilakukan oleh suku Sasak sebagai penduduk asli Pulau Lombok. Khususnya penduduk Lombok selatan beserta cabang-cabang keturunannya, yaitu di Lombok Timur terdiri dari desa Sakra, Keruak, dan Jerowaru, serta di Lombok Tengah meliputi Desa Ganti, Marong, Kawo, Teruwai, Sengkol, Rambitan, Kuta, Pengembur, Ketara, Tanaq Awu, Penujaq, Mangkung, Batujai, Sukarara, dan Bonjeruk. Keajaiban nyale bagi suku Sasak di Lombok telah menimbulkan dongeng tentang kejadiannya yang tersebar hampir di seluruh lapisan masyarakat SasakLombok dan sekitarnya. Dongeng ini sangat menarik dengan cerita yang sangat romantis dan berkembang melalui penuturan orang-orang tua yang kemudian tersusun dalam naskah tentang legenda nyale.

Penangkapan nyale menjadi tradisi turun-temurun di pulau Lombok (khususnya bagian Lombok Selatan, kabupaten Lombok Timur dan Tengah). Pada saat acara bau nyale yang dilangsungkan sekarang ini, sejak sore hari mereka yang akan menangkap nyale berkumpul di pantai mengisi acara dengan peresean, membuat kemah dan mengisi acara malam dengan berbagai kesenian tradisional. Misalnya, bêkayaq (istilah di wilayah Jerowaru, Lombok Timur) atau betandaq 'berbalas pantun' (di wilayah Kuta, Lombok Tengah), berubaq/bejambeq (pemberian cendera mata kepada kekasih), serta belancaran (pesiar dengan perahu). Tak ketinggalan pula, digelar drama kolosal Putri Mandalika. Tradisi inilah yang saat ini sangat ramai dikunjungi wisatawan dalam negeri dan asing.

Waktu pelaksanaan bau nyale didasarkan pada perhitungan/penanggalan masyarakat Sasak agraris. Setiap tahun penangkapan nyale berlangsung pada tanggal 19 dan 20 bulan sepulu 'sepuluh' (bertepatan dengan bulan Februari) untuk nyale tunggak 'nyale awal' dan bulan solas 'sebelas' (Maret) untuk nyale poto 'nyale akhir' dalam penanggalan Sasak agraris. Awal tahun Sasak ditandai dengan terbitnya bintang Rowot. Bintang Rowot (Rasi paliades L.) akan terus tampak setiap malam selama 6 bulan. Demikian menurut cerita dari beberapa informan. Pada tahun ini (2015), penangkapan nyale tunggak bertepatan dengan tanggal 9 dan 10 Februari 2015. Orang-orang paling ramai datang menangkap nyale pada nyale tunggak. Di samping itu, masyarakat setempat percaya bahwa banyaknya jumlah nyale yang tertangkap 
dapat dijadikan gambaran tentang kesuburan tanaman padi dan hasil panennya pada tahun itu. Oleh karena itu, nyale, bekas airnya, pemanggang (ancak) dan daun pelapis saat dibuat pepes (nyale ancak) biasanya disebar sebagai pupuk ke tengah tanaman padi serta ditancap di jalur masuknya air.

Khusus kegiatan bêkayaq dalam konteks bau nyale, para peserta dari kelompok pria biasanya menjelang sore berjalan-jalan di depan kemah gadis/janda yang dituju. Salah satu dari mereka menemui orang tua atau orang yang dituakan di dalam kemah itu. Bahwa nanti malam mereka akan datang ke dekat kemah untuk bêkayaq. Dalam satu tenda/kemah biasanya dihuni oleh satu keluarga atau lebih. Kalau ada dari luar keluarga dekat, biasanya mereka masih ada hubungan kekerabatan. Posisi kemah orang-orang yang datang menangkap nyale ini biasanya berdekatan, terutama yang dari satu kampung. Pada waktu yang sudah disepakati, sekelompok laki-laki datang untuk beradu kayaq dengan pihak/kelompok perempuan (yang di dalamnya ada gadis/janda yang disukai pihak pria).

Sementara itu, dalam konteks panen padi (pataq pare), setelah beberapa bulan (seusai bau nyale) tibalah musim mataq 'memanen padi'. Sebelum tahun dua ribuan (2000-an), petani Sasak-Lombok (khususnya di Lombok bagian selatan) masih banyak menanam padi besar atau varietas padi lokal. Bahkan, sebelum ditemukannya varietas padi unggulan (jenis IR), petani setempat umumnya menanam padi besar (khususnya jenis padi bulu). Saat itu pengerjaan sawah masih sangat tergantung dengan tenaga manusia, sehingga hampir semua aktivitas budidaya padi mengandalkan tenaga manusia. Di samping itu, pekerjaan di sawah masih jarang menggunakan sistem upah (dengan uang). Mereka lebih banyak bergantung pada sistem kerja sama, seperti ngipuk/bêtulung dan bêsiru.

Keadaan semacam itu kemudian membuka peluang bagi kaum pria untuk datang mengunjungi gadis/janda yang sedang memiliki pekerjaan di sawah seperti panen padi. Kegiatan bertandang ke perempuan yang sedang memanen padi ini disebut ngujang. Tujuan kelompok pria tersebut adalah untuk membantu memanen padi (mataq pare) sambil menyambangi gadis/janda yang disukainya. Kedatangan mereka ini biasanya karena diundang/dipesan saat bertemu pada bau nyale. Atau juga janjian ketika si laki-laki datang bertandang ke rumah gadis/janda (datang midang). Jika si pria bertempat tinggal jauh, biasanya dia akan menginap di rumah teman atau kenalannya di kampung tempat si gadis tinggal. Ketika waktu panen padi telah dimulai, mereka pun bertemu di sawah. Biasanya, baik pihak pria ataupun perempuan, sama-sama berkelompok. Di tengah-tengah kelompok mereka masing-masing terdapat seorang ahli menyusun bait pantun Sasak (buaq kayaq) 
secara sepontan. Seseorang yang ahli menyusun buaq kayaq ini disebut sinden atau pujangge. Sang pujangge dari setiap kelompok inilah yang dengan sigap menyusun dan membisikkan ke anggota kelompoknya untuk menyambut lantunan kayaq dari kelompok lain yang baru selesai dengan buaq kayaq yang selaras.

Dengan demikian, bêkayaq bau nyale dan bêkayaq pataq pare memiliki benang penghubung, yakni adanya kegiatan berbalas pantun yang dilagukan dan pelakunya adalah pihak/kelompok pria dan wanita. Tujuannya adalah menyampaikan perasaan masing-masing. Membuka model interaksi yang lebih dekat, terbuka, dan komunikatif. Jika bêkayaq bau nyale bisa menjadi kunci pembuka sekat-sekat sosial dan budaya yang selama ini terbelenggu, maka ketika sudah terbuka celah keterbukaan itu akan berlanjut pada bêkayaq saat musim panen padi (mataq). Perbedaannya adalah setting lokasi dan waktu terjadinya peristiwa tradisi bêkayaq tersebut.

\section{Bêkayaq Bau Nyale}

Bêkayaq secara harfiah berarti 'kegiatan berbalas pantun'. Sementara secara definitif dapat diartikan sebagai kegiatan berbalas pantun dalam bahasa Sasak antara sekelompok laki-laki dengan sekelompok wanita (yang kebanyakan masih berstatus lajang) dalam rangkaian tradisi bau nyale dan pataq pare. Istilah bêkayaq digunakan oleh masyarakat yang menangkap nyale di pantai Kaliantan dan Sungkun (kecamatan Jerowaru, kabupaten Lombok Timur). Masyarakat tersebut datang dari wilayah Jerowaru, Keruak, Sakra (kabupaten Lombok Timur) dan Praya Timur (kabupaten Lombok Tengah). Istilah lain yang bersinonim dengan istilah bêkayaq adalah bêtandaq. Istilah yang kedua ini lazim digunakan oleh masyarakat Sasak yang menangkap nyale di kawasan pantai Seger (Kuta, Lombok Tengah). Jadi, istilah bêkayaq dan bêtandaq adalah sama maknanya. Perbedaan istilah menandakan adanya perbedaan dialek bahasa Sasak yang digunakan dan wilayah penangkapan nyale yang berbeda, yakni di dua kawasan pantai utama pulau Lombok yang sama-sama berada di bagian selatan pulau Lombok.

Selanjutnya, dalam konteks bêkayaq bau nyale, acara bêkayaq biasanya dilakukan pada sore hari (hari pertama mereka datang ke lokasi bau nyale) atau pada malam hari (malam kedua atau ketiga). Biasanya sekelompok pria (mayoritas bujangan) dari suatu kampung berjalan bersama-sama melewati depan kemah yang dihuni oleh beberapa orang gadis dan janda dari suatu kampung. Kegiatan melewati depan kemah gadis tersebut dinamakan bêgêros. Pada saat bêêeros ini, sekelompok pria 
tersebut mulai angkat kayaq (mengangkat lantunan pantun yang dilagukan khas Sasak) dengan sama-sama bêkayaq mengucapkan buaq kayaq (bait pantun) pembuka.

(1) Rarit jangan laguq liyat Ndeq yaq liyat kedung jari jangan Tabeq walar yaqke liwat Ndeq yaq liwat kedung jari jalan.
‘Dendeng daging tapi liat

Tidak akan liat sudah terlanjur jadi daging Permisi saya mau lewat

Tidak saya lewat (sini) sudah terlanjur jadi jalan.'

Bait pantun di atas merupakan semacam bahasa permohonan izin (pênabeq) untuk berjalan di depan kemah sekelompok gadis yang sedang dituju. Dalam satu kemah biasanya tinggal beberapa orang gadis/janda dari satu kampung atau dari kampung yang berbeda tapi masih ada hubungan keluarga, dan dalam kemah tersebut dijaga oleh beberapa orang tua sebagai pengemong. Para gadis/janda yang tinggal di dalam kemah tersebut kemudian mulai keluar dengan dandanan yang rapi sembari berdiri di depan kemah. Jika sudah demikian berarti acara bêkayaq sudah siap dilakukan. Rombongan pria yang tadi lewat di depan kemah itupun berkumpul mendekati sekelompok wanita tersebut. Mereka kemudian berhadap-hadapan dengan jarak 3 hingga 4 meter. Sekelompok pria tadi mulai angkat kayaq sebagai tantangan dengan mengatakan:

(2) Bageq malang to Semawaq Mentaram balen gendit Tabeq walar yaqke bêkayaq Kendeq paran ndarak tertip.
'Pohon asam melintang di Sumbawa

Mataram tempat gêndit ${ }^{3}$

Permisi saya mau bêkayaq

Jangan sampai dikatakan tidak tahu aturan.'

Setelah buaq kayaq tersebut diucapkan, group wanita pun menjawab dengan mulai menanyakan nama mereka melalui bait pantun. Kedua kelompok beda lawan jenis ini akan terus saling menimpali, menyampaikan perasaan mereka hingga kadang-kadang menyatakan kesiapan mereka untuk menikah sehingga ada jodoh. Lihat pada bait pantun (buaq kayaq) yang mereka ekspresikan di bawah ini.

(3) Buaq rampeq saq leq rereq Olah-olah daun jeluang Lamun uah sampe yaq kemeleq Ane keruanang unin angen.

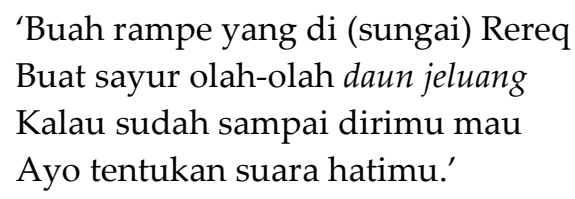

\footnotetext{
${ }^{3}$ Sejenis kalung yang dipakai praja saat mengarak pengantin, terbuat dari selake 'emas campuran'.
} 
(4) Pait poteng jari kaken

Beli nangke saq to Sepit

Aoq mas kakaq uah taq keruan angen

Ketunas lempot lalo pelesir.
'Pahit rasa tape buat dimakan

Beli nangka yang ada di (desa) Sepit

Ya sudah kanda, hatiku sudah memastikan

Saya minta selendang untuk pergi pelesir.'

Petikan bait pantun di atas menggambarkan bagaimana dalam acara bêkayaq terjadi keterbukaan interaksi antara gadis dan pemuda atau antara duda dengan janda yang diekspresikan melalui media bahasa yang bernama pantun (kayaq). Tidak hanya itu, aktivitas bêkayaq sebagai sebuah tradisi dalam bau nyale pada tingkat yang sangat praktis, penggunaan "komunikasi ritual" berupa kayaq selama bau nyale telah menjadi media untuk bertindak keluar dari beberapa ketegangan yang terasa ada dalam masyarakat Sasak. Lewat bahasa kayaq/pantun pola hubungan sosial yang normal "dihentikan", pola "bahasa ritual" bebas ungkap dikenakan sebagai gantinya. Dengan demikian, bêkayaq bisa dikatakan sebagai media ekspresi perasaan yang "diritualkan" melalui kayaq Sasak (cf. Ecklund, 1977).

Bau nyale yang setiap tahunnya sangat ramai dikunjungi masyarakat SasakLombok bagian selatan, terutama kaum muda-mudinya, tidak hanya sebatas tradisi menangkap nyale. Akan tetapi, secara sosial maupun psikologis-komunal tampaknya bau nyale telah menjadi salah satu media "pembebasan" kaum muda-mudi dari kungkungan dan tekanan budaya yang sangat menjaga pola-pola budaya dalam mengatur pergaulan kaum pria dan wanita. Tidak heran jika pada musim bau nyale ini, gadis-gadis Sasak yang tinggal di desa dan datang bau nyale menghabiskan banyak dana untuk persiapan pergi bau nyale. Mereka harus memakai pakaianpakain terbaiknya dan bahkan membeli pakaian-pakain baru dan beragam perlengkapan bau nyale seperti payung dan sorok bau nyale. Sementara itu, bagi kaum muda (pria) peristiwa budaya ini telah menjadi media pelepasan penatnya bekerja di sawah atau pergi berburuh dan tak jarang menemukan jodohnya di lokasi bau nyale. Tidak jarang mereka kawin lari (merariq) lewat tempat bau nyale, tanpa si gadis/janda harus pulang terlebih dahulu ke rumahnya untuk memberi tahu orang tuanya.

Di bagian akhir acara bêkayaq, buaq kayaq yang dilagukan adalah bait perpisahan. Ungkapan buaq kayaq yang mereka ucapkan seperti berikut.

(5) Terang bulan leq pesisi Sapuq tangan bongkosang sabun Saya pulang minta permisi Mari tangan minta ampun.

(6) Mun kemalun lengkarang tunuq Mun telage Batu Putiq
'Terang cahaya rembulan di tepi pantai Sapu tangan pembungkus sabun Saya pulang minta permisi Mari (berjabat) tangan (tanda) minta ampun.'

'Kalau pohon kemalun dan lengkarang dibakar Kalau kolam di Batu Putiq 
Lamunne lalo besalam juluq

Deq solah angen lampaq uleq.
Jika kau pergi berjabatlah tangan dulu

Supaya hati ini tenang berjalan pulang.'

Jika beberapa contoh buaq kayaq di atas disampaikan dalam bentuk nyanyian (kayaq) langgam Sasak, akan ditemukan pola seperti terlihat dalam Tabel 2. Jumlah baris buaq kayaq yang semulanya berjumlah empat baris, setelah mengalami pengulangan dalam nyanyian, berubah menjadi dua belas baris. Contoh dari data (56) dapat dilihat di bawah ( $c f$. Ecklund, 1977).

\section{Tabel 2. Formula Buaq Kayaq (Bait Pantun) yang Di-kayaq-kan pada Bau Nyale}

\begin{tabular}{lll}
\hline No. & \multicolumn{1}{c}{$\begin{array}{c}\text { Bait pantun (5) yang dikayaqkan oleh } \\
\text { pria }\end{array}$} & \multicolumn{1}{c}{$\begin{array}{c}\text { Bait pantun (6) yang dikayaqkan oleh } \\
\text { perempuan }\end{array}$} \\
\hline 1. & $\varphi$ Terang bulan nala leq pe-la-sisi & $\varphi$ Mun kemalun nala lengkarang la tunuq \\
2. & $\varphi$ Leq pesisi nala ri ala terang & Nala lengkarang nala ri ala mun ke \\
3. & $e$ Terang bulan nala leq pe-la-sisi & Nala mun kemalun nala lengkarang la tunuq \\
4. & $\varphi$ Sapuq tangan nala bongkosan la sabun & Nala mun telage nala batu $\varphi$ putiq \\
5. & $\varphi$ Bongkosan sabun nala ri ala nare & Nala batu putiq nala ri ala nare \\
6. & $e$ Naro silaq side ma-se-la-meton. & Nala naro la silaq side ma-se-la-meton. \\
7. & $e$ Saya pulang nala minta la permisi & $e$ Lamun ne lalo mas kakaq besalam la juluq \\
8. & $\varphi$ Permisi nala ri ala saya & $e$ Besalam juluq nala ri ala lamun \\
9. & $\varphi$ Saya pulang nala minta la permisi & $\varphi$ Lamun ne lalo mas kakaq besalam la juluq \\
10. & $e$ Mari tangan nala minta la ampun. & $\varphi$ Deq saq solah angen mas kakaq lampaq la \\
11. & Saq manggi nari nala ri ala nare & uleq \\
12. & $\varphi$ Naro la silaq side ma-se-la-meton. & Nala lampaq uleq nala ri ala nare \\
& & Nala naro la silaq side ma-se-la-meton. \\
\hline
\end{tabular}

Keterangan: Simbol $\varphi$ menunjukkan sebuah pilihan untuk diam menarik nafas (sementara waktu).

Dari perspektif etnopuitik, tampak bahwa buaq kayaq (bait pantun) Sasak tersebut dibalut dengan ciri khas lokal Sasak. Kata-kata (bahkan frase dan kalimat) yang dicetak miring tersebut awalnya tidak ada dalam buaq kayaq. Namun, ketika buaq kayaq tersebut dinyanyikan dengan khas langgam kayaq Sasak, kata-kata tersebut harus muncul sebagai pembentuk formula khusus kayaq. Kata-kata tersebut ada yang memiliki arti dan ada juga yang tidak punya arti (leksikal). Secara rinci kata-kata khas sisipan dalam buaq kayaq itu adalah: nala, la, nala ri ala, nala ri ala nare, naro silaq side ma-se-la-meton, saq manggi nari nala ri ala nare, dan naro la silaq side ma-sela-meton.

Kata nala, la, dan ala merupakan satu bentuk yang mengalami pemenggalan demi menciptakan ritme keseimbangan pada kayaq. Kata la dan ala berasal dari kata nala. Secara harfiah, kata-kata tersebut sulit ditemukan artinya, namun baru dapat 
dimaknai ketika berada dalam deretan buaq kayaq, sehingga (mungkin) berarti 'kalau begitu'. Kemudian, kata nari dan ri berarti 'adik'. Namun, ketika diucapkan oleh pihak perempuan kata-kata ini cenderung sebagai penyelaras kayaq semata. Munculnya bentuk nala ri adalah berasal dari na(la)ri. Kalaupun kata nala muncul diawal kayaq (angkat kayaq) merupakan pola khusus yang digunakan untuk menyambung kayaq. Kata naro dan nare merupakan bentuk yang diambil dari kata nari. Perubahan vokal /i/ menjadi /o/ dan /e/ merupakan pengaruh dari posisi kata tersebut dalam kayaq untuk membentuk sanjak (rima) yang seimbang. Sementara kata silaq 'silahkan', side 'engkau', ma-se-la-meton 'mas saudara' merupakan satu rangkaian (dalam kayaq) yang tak dapat dipisahkan dalam membentuk makna sapaan yang santun. Rangkaian kata-kata tersebut dapat diterjemahkan menjadi 'silahkan engkau wahai mas saudara/saudari'.

Dari sisi alunan lagunya yang panjang dan mendayu-dayu, jelas pola kayaq dalam bau nyale adalah tergolong panjang. Oleh para pelakunya, alunan lagu kayaq (yang mencapai 12 baris) ini disebut agon kayaq ngedonan 'lagu kayaq lambat'. Ini tampaknya dikarenakan oleh situasi santai yang melatarinya dan lokus (geografis) peristiwanya yang berada di ruang publik. Suara sahut-menyahut (balas-membalas) kayaq antarkelompok menimbulkan gelombang irama sendiri di tepi pantai yang diiringi deburan ombak pantai selatan. Tidak heran kalau waktu yang dihabiskan untuk acara bêkayaq bau nyale ini bisa tujuh hingga delapan jam. Ditambah lagi suasana kerumunan orang-orang yang datang menangkap nyale dan menonton peristiwa budaya tersebut. Jumlah bait kayaq yang di-kayaq-kan bisa mencapai lima hingga enam puluhan buaq kayaq. Bait kayaq yang disajikan dalam tulisan ini terbatas sebagai contoh saja.

Berakhirnya buaq kayaq penutup tersebut menandai berakhirnya bêkayaq bau nyale antardua kelompok yang beda jenis itu. Inilah akhir pertemuan mereka dalam tradisi bau nyale tahun ini. Jika mereka misalnya sudah saling merasa cocok, banyak dari mereka yang melanjutkan pertemuan tersebut sehingga si pria datang ke rumah si wanita hingga mereka pun menikah. Namun jika mereka tidak merasa cocok, cukuplah perkenalan mereka sampai di lokasi bau nyale saja. Dengan demikian, bau nyale khususnya bagi kaum mudanya (sadar atau tidak) telah membawa perubahan yang terjadi dalam masyarakat Sasak dan sekaligus adalah konsekuensi dari perubahan jaringan sosial. 


\section{Bêkayaq Pataq Pare}

Memasuki masa panen padi, masyarakat Sasak (khususnya pemudapemudinya) pada waktu dahulu disibukkan oleh pekerjaan di sawah. Dalam kegiatan panen padi mereka biasanya mengambil siru (sesama kaum wanita), yakni sejenis sistem kerja sama yang bergiliran. Sehingga tidak heran mereka (terutama yang memiliki sawah yang luas) bisa sebulanan berkeliling dan bergantian puliq siru 'membalikkan siru' terhadap orang yang pernah datang mengambil siru (bait siru). Jika keluarga itu memiliki anak gadis atau janda, secara tidak langsung, dapat menjadi investasi dalam meringankan pekerjaan sawah, khususnya saat panen padi (mataq). Karena gadis/janda yang akan melaksanakan panen padi di sawahnya, biasanya ditanya oleh jejaka atau lelaki yang menaruh hati padanya. Kapan akan dilaksanakan panen padi di sawahnya. Atau si pria sudah berpesan saat berjumpa di bau nyale (beberapa bulan sebelumnya) agar diberitahu kapan dia akan panen padi. Jika tempat rumah si pria berjauhan dengan si perempuan, biasanya ada penitipan salam (sempait salam) lewat teman atau kerabat pria yang dikenal oleh gadis/janda itu, mengenai waktu akan dilaksanakan panen padi.

Menyimak pengalaman para pelaku bêkayaq di saat panen padi itu, dapat dikatakan bahwa kaum muda-mudi Sasak (pada waktu dahulu) sama-sama menjadikan peristiwa pataq pare sebagai lokus perjumpaan lanjutan (pasca-bau nyale) untuk dapat saling kenal lebih dekat. Menurut informan, kelompok pemanen padi dari pihak perempuan (yang di dalamnya ada gadis/janda) biasanya pagi-pagi sudah hadir di sawah tempat pataq pare berlangsung sebelum kelompok pria datang. Dalam rombongan kaum hawa ini terdapat seorang ahli pembuat pantun (buaq kayaq). Mereka menyebutnya pujangge (sinden). Yang menjadi sinden biasanya seorang wanita (senior) yang sangat ahli mengarang dan merangkai buaq kayaq. Ia biasanya menciptakan buaq kayaq yang sesuai dengan buaq kayaq yang dilontarkan oleh pihak pria. Dari buaq kayaq yang diciptakan ini lalu dilagukan (di-kayaq-kan) bersama-sama untuk menimpali kayaq dari pihak laki-laki.

Jika bêkayaq bau nyale berlangsung secara paralel dan waktunya bisa sore atau malam hari. Sebaliknya, bêkayaq pataq pare berlangsung dalam beberapa fragmen dan waktunya berlangsung dari pagi hingga sore hari. Mereka biasanya beristirahat untuk makan-minum dan solat (sembahyang-salat). Bêkayaq pataq pare bisa juga dilakukan oleh sekelompok saja, yang dalam konteks ini berarti tidak ada lak-laki yang datang atau berkunjung membantu (ngujang) pataq pare. Sementara yang dimaksud dalam kajian ini adalah bêkayaq pataq pare yang dilakukan antarpria dan wanita saat ada kelompok pria yang datang ngujang ke sawah tempat panen padi 
sedang berlangsung. Ketika panen padi sudah mulai, kelompok wanita membuat arah panen tersendiri (andang mataq) sehingga bisa kompak dalam bêkayaq. Begitu pula dengan kelompok pria, mereka membuat andang mataq sendiri, tapi masih tetap dalam satu petak sawah dengan kelompok wanita. Di bawah terpaan terik matahari pagi, pihak pria mulai angkat kayaq dengan kayaq pembuka.

(a) Rampeq bayan leq Semawaq

Anak jaran saq to Sepit

Tabiq walar yaq ke bêkayaq

Engkah paran ndaraq tertip

\author{
'Bunga rampeq bayan di Sumbawa \\ Anak kuda yang di Sepit \\ Permisi saya akan bêkayaq \\ Jangan kira tidak punya tata krama.'
}

Ada juga versi lain dari pembuka kayaq, yakni: Rampeq bayan leq semawaq / anak jaran bekasuran/Tabiq walar yaq ke bêkayaq/engkah paran ndaraq aturan. Selelesai buaq kayaq pembuka tersebut di-kayaq-kan oleh kelompok pria, pihak perempuan langsung menyonsongnya dengan mengatakan buaq kayaq berikut.

(b) Beli rokoq araq lime

Anak kau dalem kebon

Yaq ketontoq maniq side

Ndeqke tao mas semeton
'Beli rokok ada lima

Anak kerbau (ada) di dalam kebun

Kami akan timpali perkataan anda

Kami tidak sanggup mas saudara.'

Setelah sama-sama membuka kayaq dengan buaq kayaq di atas, acara adu pantun kayaq (papasan bêkayaq) diantara kedua belah pihak terus berlanjut. Papasan bêkayaq akan berjalan dengan lancar apabila pihak lawan menyusun kayaq-nya dengan sistematis, terutama dari pihak laki-laki sebagai pendahulu (pemantik). Pihak perempuan sebagai penyambut akan segera menyusun buaq kayaq untuk membalas buaq kayaq dari pihak pria. Para mantan sinden bêkayaq (perempuan) menceritakan: "Lamun kenaq dolor buaq kayaq saq mame nuq, becat te pinaqang lendong buaq kayaq. Lamun ndeq kenaq dolor jaq ye ampuq saq ngunder buaq kayaq, ndeq iniq beratas." 'Kalau benar urutan bait pantun dari kelompok pria itu, kita cepat membuatkan sampiran/kulit (untuk membalas kayaq)nya. Namun, apabila tidak benar urutannya, itu sebabnya buaq kayaq (dari kedua belah pihak) tidak bisa lancar, berputar di buaq kayaq semula.

Menurut mantan para pelaku bêkayaq pataq pare, yang paling sulit dalam bêkayaq adalah mengkomposisi sampiran/kulit pantun (lendong buaq kayaq). Ini dikarenakan adanya tuntutan untuk menyeimbangkan buaq kayaq dengan buaq kayaq yang dikayaq-kan pihak lain. Di sisi lain, mereka harus tetap konsentrasi dengan pekerjaan mengetam padi sehingga tangannya tidak terkena mata ani-ani (mangan rangkap). 
Jika salah satu kelompok keliru dalam menyusun buaq kayaq akan ditertawakan oleh kelompok yang lain. Di sinilah persoalan harga diri (yang berimbas secara psikologis dan sosial) dari pihak laki-laki dan wanita dipertaruhkan untuk menjaga kelompok masing-masing. Yang paling berkepentingan (tentunya) adalah sinden, pengarang/komposer buaq kayaq.

Dalam berbalas kayaq ini terjadi istilah mame juluan beratas buaq kayaq. Artinya, pihak prialah yang harus melemparkan buaq kayaq terlebih dahulu. Atau juga berarti, pihak laki-lakilah yang yang terlebih dahulu menaikkan isi buaq kayaq-nya. Dalam hal ini, tak jarang pihak laki-laki buaq kayaq-nya sampai mengajak pada pernikahan dengan ajakan ke penghulu. Ini biasa terjadi saat buaq kayaq dari kedua belah pihak terus berjalan dengan lancar. Tidak ada dari salah satu pihak yang mancet (kalah) dalam mengkomposisi buaq kayaq-nya. Dalam konteks ini yang paling berperan (sekali lagi) adalah sinden kayaq, seseorang yang menjadi komposer buaq kayaq yang ada di tengah-tengah dari setiap kelompok. Tak jarang yang sebenarnya "bermusuhan" dari kedua belah pihak adalah para sinden. Semakin tak terkalahkan semakin terkenallah sinden tersebut dalam bêkayaq. Menjelang berakhirnya bêkayaq, ditandai dengan lantunan bait kayaq di bawah ini dan sekaligus menandai hari sudah sore.

(c) Kaken sie sedaq banget Mun rembaong bare liang Mbe niye epen bangket Ndeq ketaon jage jelo biyan

\author{
'Makan garam campur jajan banget \\ Kalau rebung (di kampung) Bare Liang \\ Mana dia pemilik sawah \\ Mungkin tidak tahu hari sudah sore.'
}

Begitu mendengar buaq kayaq ini dilantunkan, pemilik sawah biasanya bergegas mendekati orang-orang yang sedang mataq untuk mempersilahkannya naik/berhenti. "Aneh taeq ane semeton jari, uah biyan uah." 'Silahkan naik saudara semua, ini sudah sore.' Mereka pun mulai bersiap naik sambil berbalas kayaq sekali lagi sebagai tanda perpisahan (periksa Tabel 3, kayaq perpisahan dan cara pelantunannya). Lebih lanjut, menurut riwayat dari informan, mereka tidak akan pernah naik (berhenti mengetam padi) sebelum dipersilahkan oleh pemilik sawah untuk berhenti/naik. Sehingga seandainya hari sudah terlalu sore, mereka terpaksa menyindir pemilik sawah dengan buaq kayaq di atas. 


\section{Tabel 3. Formula Buaq Kayaq (Bait Pantun) yang Di-kayaq-kan pada Pataq Pare}

\begin{tabular}{lll}
\hline No. & Kayaq kelompok pria & Kayaq kelompok wanita \\
\hline 1. & Gogor gonde nariq mulen manis & Bagus cedang nariq dile lilin \\
2. & Mulen manis se-meton nala gogor & Do kaye se-meton nala bagus \\
3. & Gogor gonde naro kaye mulen manis & Bagus cedang nariq dile lilin \\
4. & Gonde ringkah nariq alung telage & Mun bejait nariq dasan repoq \\
5. & Side ma-se-la-meton nala naro & Do kaye se-meton ala naro \\
6. & Aro edur polang nariq melengku nangis & Bagus entan ariq saling belen \\
7. & Side mas se-la-meton nala edur & Do kaye semeton nala bagus \\
8. & Edur polang inaq melengke nangis & Bagus ntan ite tesaling belen \\
9. & Pole tingkah inaq bareng nerake & Mun bedait ariq kendek tedoq \\
& Do kaye se-meton nala naro & Do kaye se-meton nala naro \\
\hline
\end{tabular}

Dilihat dari jumlah baris kayaq yang ada di bêkayaq bau nyale dan bêkayaq pataq pare terlihat ada perbedaan. Baris kayaq dalam kayaq bau nyale berjumlah 12 baris, sedangkan dalam kayaq pataq pare berjumlah 10 baris. Ini dikarenakan oleh jenis nada lagu (agon kayaq) yang berbeda. Dalam konteks bau nyale menggunakan agon ngedonan 'nada lagu lambat', sementara dalam pataq pare memakai agon bejonjaq 'nada lagu agak cepat'.

Selanjutnya, sangat ironis keberadaan bêkayaq pataq pare sudah tidak ditemukan lagi di tengah-tengah masyarakat Sasak agraris. Ini terjadi seiring/paralel dengan keadaan transisi masyarakat Sasak agraris (baca: petani tradisional) menuju masyarakat industri, bahkan masyarakat teknologi. Mereka sudah tidak lagi menanam varietas padi lokal (yang lazim dipanen dengan ani-ani dan mayoritas dikerjakan oleh kaum wanita). Dalam budidaya padi hampir seluruhnya menanam padi varietas unggulan (jenis padi IR) yang pemanenannya didominasi kaum pria saat mesin sudah mulai digunakan untuk perontokannya. Akibatnya, peran kaum wanita dalam hal urusan logistik pangan sudah terabaikan dan digusur. Padahal, dahulunya perempuanlah yang menjadi simbol kedaulatan pangan (cf. Ibnouf, 2009). Ini terlihat dari istilah-kebahasaan Sasak-Lombok yang memosisikan wanita dipercayai sebagai pemegang kedaulatan pangan, seperti istilah inen meniq 'ibu beras', inen buyuq atau inen pare 'induk padi', dan inen bale 'induk rumah'.

Sementara di sisi lain, dengan tidak ditanamnya lagi jenis padi lokal dan tidak dilibatkannya kaum perempuan dalam hal panen padi, secara nirsadar ini berdampak terhadap hilangnya tradisi bêkayaq pataq pare di kalangan masyarakat Sasak. Masyarakat Sasak agraris (di luar komunitas Bayan, Lombok Utara dan Sembalun, Lombok Timur) sudah memakai logika profit industri tanpa menyadari 
dan memikirkan resiko produksi. Inilah yang menjadi penyakit masyarakat industri, termasuk yang menimpa masyarakat Sasak agraris (khususnya petani padi). Dalam konteks ini terlihat jelas relasi bahasa dan budaya, baik dalam hal kebertahanan ataupun kepunahan, terlebih lagi didukung oleh perilaku dan sikap masyarakat pemilik budaya tersebut.

\section{Representasi Perilaku Liminal dan Arah Perubahan Perilaku Masyarakat Pelaku Bêkayaq}

Bahasa puitis tidak hanya berfungsi sebagai media-komunikasi-verbal pembungkus makna, namun ia hadir sebagai totalitas bahasa yang hidup dengan ruhnya sendiri. Ia muncul untuk menggelitik, mengejek, memecah, merobek, atau medobrak. Ia adalah suara hati nurani yang sedang menyapa hati nurani yang lain (Kadarisman, 2010). Begitu pula dengan buaq kayaq yang dilantunkan saat bau nyale maupun pataq pare. Bait-baitnya sederhana, tetapi ia bergerak dari kulit menuju isi. Di kulitnya terlihat prinsip keseimbangan yang tersurat dari cara menentukan pemilihan diksi, rima, hingga makna (pada poros paradigmatik) untuk diproyeksikan pada poros sintagmatik, sehingga menghasilkan bahasa yang puitis. Sementara dari sisi isi (maknanya) tersirat beragam pergolakan batin yang hendak menyapa kesadaran lawan tuturnya.

Bêkayaq (bau nyale dan pataq pare) dilihat dari persoalan sosial-psikologis, bukan hanya sebatas ungkapan ekspresi simbolik antar-kedua lawan jenis. Lebih dari itu, bahasa kayaq adalah usaha verbal untuk membuka ruang lentur relasi antara kaum wanita dan pria Sasak-Lombok pada ranah publik. Usaha verbal ini tampaknya muncul dalam (masyarakat Sasak agraris) guna membuka garis tengah (ruang publik) yang selama ini kental dikuasai budaya patrilineal, sehingga hubungan lakilaki dan perempuan (khususnya kaum mudanya) dikendalikan sepenuhnya dalam pola komunikasi subjek dan objek. Akibatnya, pola hubungan dalam kehidupan merekapun cenderung hierarkhis dan non-egaliter, baik dalam rumah tangga, keluarga, maupun masyarakatnya.

Dengan adanya kegiatan bau nyale dan pataq pare serta diadakannya tradisi bêkayaq antara kaum pria dan wanita, bisa dikatakan bahwa bêkayaq adalah wujud gambaran keadaan masyarakat Sasak agraris yang sudah meninggalkan fase praliminal menuju fase liminal. Ini bisa dibuktikan lewat perilaku mereka yang sudah mulai beinteraksi dalam ruang terbuka, meskipun masih pada kegiatankegiatan yang bersifat komunal dan terbuka. Misalnya, pada tahun 70-an hingga 90an (saat tradisi bêkayaq juga masih eksis), kaum pria-muda dan wanita-muda (terune, 
dedare, atau balu) akan ditemukan berkumpul dan bekerja sama saat ada pesta (gawe). Mereka akan berinteraksi selama pelaksanaan acara tersebut. Mulai dari mengundang tamu (mênyilaq), menumbuk padi, mengangkut air, membuat jajan, menyiapkan kayu bakar, membuat rokok pilitan, dan berbagai hal terkait dengan kelengkapan dalam gawe tersebut. Semua ini dilakukan bersama-sama, sehingga komunikasi dan interaksi mereka selama acara itu begitu mencair. Meskipun demikian, tetap mereka tidak boleh berduaan di tempat yang sepi. Harus ada orang terpercaya yang menemani atau berada di tempat yang terlihat oleh orang banyak, sehingga tidak memunculkan perbuatan yang salah (salaq tingkah) atau terkena fitnah (bakat isiq tingkah).

Mengacu pada bahasa bêkayaq tersebut, ada beberapa hal terkait dengan persoalan psikologis kaum wanita-muda (dêdarê khususnya) dan kaum pria-muda (têrunê) Sasak-Lombok yang terepresentasikan. Misalnya, mereka mencoba membangun relasi psikologis yang lebih setara dan terbuka lewat media bahasa bêkayaq saat berinteraksi di ruang publik. Ini tercermin lewat penggunaan istilah: silaq sidê ma-sê-la-mêton (berasal dari: silaq sidê mas sêmêton 'silahkan engkau mas saudara/saudari'). Baik laki-laki maupun perempuan sama-sama menggunakannya dalam menyelaraskan nada kayaq dan menggelitik lawan tuturnya. Namun di samping itu, mereka juga sulit keluar dari pakem aturan sosial-budaya setempat. Artinya, baik kaum pria ataupun wanita muda pada khususnya, tidak bisa terlepasbebas dari pengaruh sosial-budaya meskipun dalam ruang dan waktu tertentu, seperti dalam kegiatan bau nyale dan pataq pare.

Seorang informan wanita menyatakan pengalamannya dalam bêkayaq: "Laguq saq kênê kakaq doang ndeqtê gaweq laeq, ndeqte sêmên." 'Namun mengatakan seperti kakak saja (dalam bêkayaq) tidak berani kita lakukan dahulu, kita tidak pantas.' Pernyataan ini secara eksplisit menjelaskan bahwa secara sosial-psikologis, wanita (yang sedang bêkayaq) merasa pemakaian bahasa-sapaan "kakak" untuk menyebut laki-laki (yang menjadi lawan bêkayaq-nya) adalah sesuatu yang tabu. Akibatnya ia/mereka harus memilih kata "mas semeton" (mas-se-la-meton dalam kayaq) atau mas kakaq untuk menyapa kaum pria itu dalam bêkayaq. Sebaliknya, data bahasa dalam kayaq menunjukkan, kaum pria tidak sungkan memakai kata "ariq" 'adik' untuk menyapa kelompok wanita yang menjadi lawan bêkayaq-nya.

Kenyataan tersebut tentu tidak bisa lepas dari latar strata sosial masyarakat Sasak-Lombok yang berlaku ketika itu. Persoalan strata sosial ini terekam dalam istilah kebahasaan penutur bahasa Sasak. Misalnya, istilah pêranggê 'sulung' yang melahirkan konsep turunan dalam pranata berupa istilah sêngakê-sêngari 'sulung- 
bungsu', jalan ninê 'usul perempuan', dan pêngêntuk/pêromboq 'pelebih/penambah'. Konsep pêranggê ini memosisikan prioritas bagi sikap-perilaku perorangan hingga menjadi modal kelompok dalam menyesuaikan kebutuhan-kebutuhan publik untuk memperoleh pemerataan bagi kepenguasaan perorangan atau kelompok. Wujud pengenaan konsep pêranggê dan dampaknya terepresentasikan dalam memutuskan suatu perkara. Kewenangan keputusan lazim dilimpahkan kepada urutan perangge antar-kedudukan dan peran, lalu kepada urutan sengari dan jalan nine 'usul perempuan'. Implikasinya adalah munculnya gaya ungkap sapaan yang ketat dan tunduk pada konsep-konsep pranata tersebut. Dengan demikian, gaya ungkap sapaan yang sengari, jalan nine, atau pengentuk (sebagai representasi kaum perempuan) kepada yang perangge/sengake harus mengikuti institusi persapaan layaknya adik kepada kakaknya, sehingga terhindar dari salaq base 'salah bahasa' dalam konteks sosial dan budaya.

Selain itu, untuk pemuda dan pemudi yang sudah berstatus pacaran (bêrayêan atau saling meleq), mereka akan berkomunikasi lebih sering dan akrab saat bau nyale dan pataq pare. Dengan begitu, ungkap-verbal yang dilakukan saat midang (bertandang untuk bertemu/berbicara dengan pacar di rumahnya) yang cenderung ekslusif dapat lebih inklusif saat bau nyale dan pataq pare. Ini seiring dengan perilaku mereka (terutama kaum pria-muda) yang sering tidak secara langsung menyerahkan perubaq 'barang-barang pemberian kepada gadis' di hadapan mereka saat midang. Begitu pula dengan si gadis yang jarang sekali secara terbuka meminta dibelikan sesuatu sebagai perubaq kepada pacarnya. Namun, ketika acara bau nyale atau pataq pare, laki-laki yang punya pacar akan membawa berbagai macam perubaq dan diserahkan secara terbuka. Bahkan, dalam hal bau nyale, pihak pria biasanya membelikan baju, kain, sandal, selendang, payung, dan beragam alat kosmetik untuk diserahkan ke pacarnya sebagai perubaq.

Menurut penuturan informan pria: "Timaq te saq berayean laeq, ite saq mamê kadang-kadang ndeq te semen êbeng pêrubaq leq julun dêdarê. Biasên te kadu subandar/jalan, bahkan poloq te oleq pêtarang manuk. Laguq lamun musim bau nyale atau ngujang pataq pare jaq sanggupte ponggoqang rik joq julun berayente. Saling jengahin kance saingante. 'Meskipun kita pacaran dahulu, kadang-kadang kita yang pria malu untuk memberikan perubaq di depan gadis (secara langsung). Biasanya kita menggunakan subandar, hingga terkadang kita taruh di tempat ayam bertelur (petarang manuk). Namun, kalau musim bau nyale atau ngujang panen padi, kita sanggup membawakannya sendiri ke hadapan pacar kita. Saling bersaing sama saingan kita'. Tuturan informan ini sendiri sebenarnya telah menjelaskan bagaimana pola interaksi 
pria dan wanita (khususnya muda-mudi atau terune-dedare) dalam ruang domestik dan ruang publik. Gambaran-gambaran perilaku mereka dalam berinteraksi dapat dilihat pada Tabel 4 di bawah ini.

\section{Tabel 4. Pola Perilaku Pergaulan Pria-Wanita di Ruang Domestik dan Ruang Publik}

\begin{tabular}{|c|c|c|}
\hline No. & Rumah (ruang domestik) & Lokasi bau nyale/pataq pare (ruang publik) \\
\hline 1. & $\begin{array}{l}\text { Ketika berbicara persoalan cinta/perasaan } \\
\text { mereka cenderung lebih banyak diam atau } \\
\text { bahasa yang pelan dan hati-hati. }\end{array}$ & $\begin{array}{l}\text { Mereka mengungkapkan perasaannya dengan } \\
\text { tegas meskipun lewat bahasa pantun. }\end{array}$ \\
\hline 2. & $\begin{array}{l}\text { Di rumah hubungan mereka lebih private } \\
\text { dan secret. }\end{array}$ & $\begin{array}{l}\text { Di lokasi bau nyale mereka lebih terbuka dan } \\
\text { umum (open dan public). }\end{array}$ \\
\hline 3. & $\begin{array}{l}\text { One-to-one dan sering menggunakan bahasa } \\
\text { pinjean (pantun tanpa dilagukan). }\end{array}$ & $\begin{array}{l}\text { Group-to-group dan cenderung memakai bahasa } \\
\text { yang jamaq (bahasa sehari-hari). }\end{array}$ \\
\hline 4. & Hubungan dimediasi oleh jalan/subandar. & Hubungan dimediasi lewat kayaq. \\
\hline 5. & $\begin{array}{l}\text { Wanita yang menerima hadiah (perubaq) } \\
\text { dari pihak pria menandakan komitmen si } \\
\text { wanita bahwa ia benar-benar mencintai si } \\
\text { pria. }\end{array}$ & $\begin{array}{l}\text { Hadiah yang diterima wanita dari pria tidak } \\
\text { serta merta menjadi pengikat cinta, namun bisa } \\
\text { jadi hanya sebatas pemberian untuk } \\
\text { persahabatan. }\end{array}$ \\
\hline 6. & $\begin{array}{l}\text { Atmosfir komunikasi antara keduanya } \\
\text { sangat formal. }\end{array}$ & $\begin{array}{l}\text { Komunikasi cenderung mencair dan penuh } \\
\text { canda. }\end{array}$ \\
\hline 7. & $\begin{array}{l}\text { Persoalan atau hal-hal yang berbau seksual } \\
\text { sangat dijaga. }\end{array}$ & $\begin{array}{l}\text { Konotasi yang berbau seksual sering } \\
\text { dilontarkan oleh pria di lokasi bau nyale. }\end{array}$ \\
\hline 8. & $\begin{array}{l}\text { Persaingan antar-pemuda yang mengapeli si } \\
\text { gadis/janda sangat tertutup dan mereka } \\
\text { sangat hati-hati. }\end{array}$ & $\begin{array}{l}\text { Persaingan antar-pemuda dalam menyapa } \\
\text { gadis/janda untuk kenalan berlangsung terbuka } \\
\text { sehingga aroma persaingan antar- } \\
\text { pemuda/kelompok pemuda tak terlalu kentara. }\end{array}$ \\
\hline
\end{tabular}

Perilaku pria dan wanita (baca: kaum muda-mudi) Sasak-Lombok, khususnya di seputaran wilayah masyarakat pendukung tradisi bau nyale, dalam konteks interaksi mereka di ruang domestik pada waktu dahulu-sadar ataupun tidaksangat "diawasi" oleh nilai-nilai ideologis-kultural yang dipegang oleh masyarakat setempat. Nilai ideologis-kultural tersebut bernama tendeh/tindih, yakni realitas kultural-religius orang Sasak (lihat Fadjri, 2015; Mahyuni, 2004, Saharudin, 2014). Nilai dasar inilah yang dulunya menjadi pegangan utama masyarakat Sasak dalam berperilaku dan bersikap. Akan tetapi, seiring dengan arus modernisasi di kalangan masyarakat agraris (khususnya), nilai etnofilosofis tersebut mulai tercemarkan, bergeser, bahkan berubah. Pola interaksi pria-wanita saat ini (terutama di lokasi bau 
nyale) jauh dari harapan ideal yang dimuat dalam etnofilosofi yang bernama tendeh. Sekarang, tradisi bau nyale sudah menggunakan logika profit produksi seperti tuntutan masyarakat industri. Implikasinya, tradisi bau nyale sudah kehilangan orientasi awal (paling tidak menurut pandangan para pelaku bau nyale terdahulu).

Selanjutnya, berdasarkan realitas budaya yang diekspresikan melalui bahasa tersebut dapat dikatakan beberapa hal tentang persoalan sosial-psikologis pria dan wanita (muda) Sasak-Lombok, terutama di wilayah/lokasi penelitian ini. Pertama, terlihat bahwa kaum pria Sasak memiliki semacam perasaan otonomi individual, sehingga mereka "berhak" menggunakan tuturan-sapaan yang eksplisit kepada lawan tuturnya, yakni kaum wanita. Kedua, tampaknya kaum wanita Sasak (khususnya yang berstatus gadis/janda) masih menyimpan semacam "produksi kecemasan sosial" (meminjam istilah Bartholomew, 2001) dalam diri mereka, sehingga menggunakan bahasa-sapaan-langsung kepada lawan tuturnya (meskipun dalam bait kayaq) mereka berusaha hindari. Ini juga tentunya tidak bisa lepas dari persoalan lokus dan tempus tempat terjadinya peristiwa tersebut. Mengacu pada dua poin ini, kaum wanita dan pria Sasak-Lombok (khususnya yang masih muda) yang tampak lebih kuat dipegang dan dipercaya adalah bahwa konsep diri dan kepribadian cenderung dimengerti sebagai hal yang tak terpisahkan dari jejaring relasi kekerabatan dan kewajiban-kewajiban sosial.

Ketiga, meskipun dua pandangan tersebut sangat representatif (berdasarkan data bahasa yang dikaji), namun ada fakta bahasa yang patut diperhatikan dari model komunikasi dalam bêkayaq ini, yaitu ditemukannya "dunia liminal" (keadaan tengah-tengah atau keadaan antara) yang dapat membuka ruang kesetaraan antara laki-laki dan perempuan, terutama dalam berkomunikasi. Ini dibuktikan lewat adanya ungkapan "side ma-se-la-meton". Ungkapan ini dalam kayaq diucapkan/digunakan oleh pria maupun wanita. Tentu secara sosial-psikologis, adanya ruang/keadaan liminal ini membawa harapan terciptanya keterbukaan dalam berkomunikasi dan kesepadanan dalam konteks sosial-budaya, terutama di ruang publik. Inilah tujuan utama budaya perilaku (behavioral culture) bêkayaq itu sebenarnya.

Representasi perilaku liminal dari masyarakat pelaku bêkayaq bau nyale dan pataq pare (khususnya di kecamatan Jewowaru, Lombok Timur), menurut pengamatan dan hasil wawancara penulis, berlangsung antara tahun 70-an sampai dengan 90-an. Yang mana pada saat itu, masyarakat Sasak bagian selatan (lokasi penelitian ini) masih berada pada masa transisi, dari masyarakat agraris (tradisional) menuju masyarakat industri-pertanian. Pada masa ini pula, masyarakat setempat 
mulai cenderung meninggalkan beberapa tradisi-budaya yang cenderung mengikat. Ini tidak lepas dari program pemerintah pada waktu itu yang mengembangkan wacana pembangunan dan modernisasi pada semua sektor kehidupan, terutama sektor pertanian di daerah tadah hujan. Tontonan melalui media televisi dan film layar tancap pada saat itu sudah disaksikan oleh masyarakat setempat, sehingga secara tidak langsung mereka mengalami kecenderungan untuk meniru. Perilaku bêkayaq yang awalnya (dalam konteks bau nyale dan pataq pare) lebih berorientasi kultural bergeser menjadi orientasi ekonomis yang ditandai dengan muncul group kesenian cilokaq (tahun 90-an). Buaq kayaq tidak lagi sebagai suara jiwa yang melukiskan gambaran-gambaran psikologis masyarakat penuturnya, tetapi lebih sebagai hiburan semata. Jadi, dapat dikatakan bahwa pada masa itulah perubahan sosial di kalangan masyarakat Sasak bagian selatan Lombok mulai terjadi.

Dalam konteks masyarakat pelaku bêkayaq bau nyale dan pataq pare, khususnya kaum muda-mudinya, perubahan sosial ini tercermin melalui pola interaksi antara wanita dan pria di ruang publik. Keberanian mereka untuk berkomunikasi secara terbuka (meskipun masih menggunakan media bahasa berupa bebalas kayaq) di ruang publik, paling tidak menandakan bahwa mereka menginginkan perubahan pola relasi dan interkasi sosial antar-sesama anggota masyarakat. Perubahan pola relasi antara wanita dan pria ini dikarenakan oleh adanya perubahan orientasi bau nyale dan pataq pare. Dahulu sebelum tahun 80-an, kegiatan bau nyale semata-mata hanya ditujukan untuk menangkap nyale supaya dapat dijadikan petanda akan tingkat keberhasilan panen padi pada tahun itu, sehingga nyale yang diperoleh sebagiannya dipakai untuk sereat/bubus 'obat' padi. Sebagiannya lagi dimakan sebagai lauk-pauk dan orang-orang yang kekurangan pangan menukarnya dengan beras. Sebaliknya, sekarang bau nyale (terutama sejak dijadikannya sebagai objek wisata oleh pemda), orientasi bau nyale berubah menjadi tontonan di ruang publik yang lebih bernilai komersialiasi, sehingga terjadi apa yang disebut ruang publik didefinisikan oleh uang. Begitu pula dengan pataq pare, yang sebelumnya kental dengan nuansa modal sosial (seperti saling bantu memanen padi-ngipuk/besiru), kini beralih menjadi lapangan pekerjaan yang berorientasi pada modal finansial yang berdampak hilangnya pola relasi sosial yang berbasis kepercayaan.

Dengan demikian, perubahan perilaku masyarakat pelaku bêkayaq bau nyale dan pataq pare dapat terlihat terutama dalam hal relasi dan interaksi kaum wanita dan pria di ruang publik. Dahulu (sebelum tahun 70-an) pola relasi/interaksi dan komunikasi pria-wanita di ruang publik mirip dengan ruang domestik, yang cenderung private dan secret. Akan tetapi, memasuki era 70-an hingga 90-an, 
perilaku tersebut mengalami perubahan menjadi pola perilaku yang bersifat liminal (meskipun masih terbatas di ruang publik tertentu). Memasuki tahun dua ribuan, di mana bêkayaq bau nyale bukan lagi sebuah kegiatan khusus bagi kaum muda-mudi di lokasi penangkapan nyale (pantai Sungkun dan Kaliantan), ataupun bêkayaq pataq pare sudah tidak ada lagi. Memasuki tahun 80-an masyarakat pendukung bêkayaq bau nyale dan pataq pare ini mulai menanam padi IR. Saat itu pula kegiatan bêkayaq pataq pare sudah berkurang, karena kaum perempuan sudah mulai berkurang peranannya dalam hal panen padi (digantikan kaum pria). Memasuki tahun 90-an kegiatan bêkayaq pataq pare digeser lagi oleh berkembangnya teknolgi komunikasi-informasi berupa tape dan pengeras suara (speaker) yang dipakai oleh sekelompok pria untuk memutar lagu-lagu dangdut dan cilokaq Sasak sambil memanen padi (mêrampek). Pada kegiatan merampek sambil memutar lagu-lagu lewat pengeras suara di sawah ini, kaum perempuan tidak lagi menjadi pelaku dalam hal panen padi. Konsekuensinya adalah terjadinya pergeseran pola interaksi yang disebabkan oleh tergesernya peran wanita dalam konteks keterlibatan pekerjaan sawah. Era 90-an ini menandakan peralihan generasi juga dalam masyarakat pelaku bêkayaq.

Di sisi lain, arah perubahan perilaku masyarakat pelaku bêkayaq tersebut memberi dampak bagi terjadinya dekonstruksi sistem sosial pedesaan, khususnya dalam konteks masyarakat agraris. Rasionalisasi usaha tani yang ditandai dengan tidak ditanamnya lagi jenis padi besar (varietas lokal) dan tergantikannya peran wanita dalam panen padi secara paralel berkaitan erat dengan hilangnya budaya bêkayaq pataq pare. Dengan kata lain, rasionalisasi dalam bidang pertanian (khusunya padi) ikut menyumbang dekulturasi kehidupan masyarakat Sasak pelaku bêkayaq. Namun, di sisi lain juga ikut membentuk pola relasi/interaksi baru dalam masyarakat tersebut. Sementara itu, perubahan orientasi bau nyale dan masuknya konsteks struktural (baca: kekuasaan) yang menguasai ruang publik, khususnya lokasi bau nyale di Kaliantan (lapangan Tampah Boleq untuk Lombok Timur dan pantai Seger untuk Lombok Tengah), telah menyebabkan lokasi kultural tersebut dan beragam tradisinya berubah dan punah. Bêkayaq bau nyale sudah digantikan dengan pentas band ibu kota. Ketika konteks struktural ada, perilaku masyarakat pendukung bau nyale yang masih memegang tata nilai, tata pikir, dan tata laku berubah menjadi kelompok pengeritik, atau hanya tidak setuju dalam sikap diam.

\section{Kesimpulan}

Berdasarkan deskripsi tentang peristiwa bau nyale dan pataq pare sebagai setting berlangsungnya tradisi bêkayaq di kalangan masyarakat Sasak-Lombok bagian 
selatan, dapat dikatakan bahwa pada tingkat yang sangat praktis, penggunaan "komunikasi ritual" atau bêkayaq selama bau nyale dan pataq pare menyediakan kanal untuk bertindak keluar dari beberapa ketegangan yang terasa atau ada dalam masyarakat Sasak pelaku bêkayaq yang esensinya menjadi tatanan norma sosial atau seperangkat aturan yang harus di taati oleh kaum pria dan wanita (khususnya kaum muda-mudinya) dalam berinteraksi dan berkomunikasi. Namun, lewat bahasa kayaq/lelakaq pola hubungan sosial yang normal itu "ditanggalkan" sementara waktu, sementara pola "bahasa ritual" dikenakan sebagai gantinya guna membuka hijabhijab sosial-budaya yang mengatur sangat ketat pola pergaulan laki-laki dan perempuan dewasa saat itu. Di samping itu, seiring terjadinya perubahan orientasi bau nyale yang ditandai dengan masuknya konteks struktural/kekuasaan, ataupun diberlakukannya rasionalisasi usaha tani (bidang padi) yang ditandai dengan hilangnya keterlibatan wanita dalam panen padi serta tidak ditanamnya lagi jenis padi lokal, beberapa realitas ini telah menyebabkan perubahan perilaku pada masyarakat pelaku bêkayaq bau nyale dan pataq pare. Bahkan, dalam konteks arah perubahan budaya, jelas ini adalah kemerosoton. Karena itu semua telah menyebabkan terjadinya dekulturasi budaya bêkayaq ke titik nadir. Pola interaksi liminal (dalam ruang publik) berubah menjadi interaksi sosial yang belum jelas arahnya. Akibatnya konstruksi identitas dari generasi tua (mantan pelaku bêkayaq bau nyale dan pataq pare) dan generasi muda terjadi. Generasi tua menginginkan ruang publik (seperti lokasi bau nyale) sebagai lokasi kultural dengan berbagai ciri khas komunalitasnya. Sementara generasi mudanya (entah sadar atau tidak) mengikuti dan menikmati perubahan lokasi kultural tersebut seiring hilangnya beberapa sistem sosial-budaya yang disimpannya. Jadi, perubahan perilaku masyarakat pelaku bêkayaq, di satu sisi, terjadi karena adanya orientasi baru dari kalangan internal masyarakat pendukung behavioral culture itu sendiri; dan di lain sisi, karena adanya penetrasi kekuasaan dari konteks struktural (baca: pemerintah).

\section{Daftar Pustaka}

Ahimsa-Putra, H.S. (1985). Etnosains dan etnometodologi: Sebuah perbandingan. Masyarakat Indonesia 12(2), 103-133.

Ahimsa-Putra, H.S. (2005). Fenomenologi gender di Jember. Musim Kawin di Musim Kemarau, Hamdanah. Yogyakarta: Bigraf.

Ahimsa-Putra, H.S. (2009). Fenomenologi agama: Pendekatan fenomenologi untuk memahami agama. Jurnal Penelitian Walisongo 17(2), 1-33.

Barker, C. (2014). Kamus kajian budaya. Alih bahasa B. Hendar Putranto. Yogyakarta: Kanisius.

Bartholomew, J.R. (2001). Alif lam mim: Kearifan masyarakat Sasak. Alih bahasa Imron Rosyidi. Yogyakarta: Tiara Wacana. 
Coulon, A. (2003). Etnometodologi. Alih bahasa Jimmy Ph. Paat. Jakarta: Kelompok Kajian Studi Kultural Jakarta dan Yayasan Lengge Mataram.

Daeng, H.J. (2008). Manusia, kebudayaan dan lingkungan: Tinjauan antropologi. Yogyakarta: Pustaka Pelajar.

Ecklund, J.L. (1977). Sasak cultural change, ritual change, and the use of ritualized language. Indonesia 24, 1-25.

Fadjri, M. (2015). Mentalitas dan ideologi dalam tradisi historiografi Sasak-Lombok pada abad XIX-XX. Disertasi doktoral, Program Pascasarjana Fakultas Ilmu Budaya Universitas Gadjah Mada, Yogyakarta.

Geertz, A.W. (2003). Ethnohermeneutics and worldview analysis in the study of Hopi Indian religion. Numen 50(3), 309-348.

Ibnouf, F.O. (2009). The role of women in providing and improving household food security in Sudan: Implications for reducing hunger and malnutrition. Journal of International Women's Studies 10(4), 144-167.

Kadarisman, A.E. (2010). Mengurai bahasa menyibak budaya: Bunga rampai linguistik, puitika, dan pengajaran bahasa. Malang: UIN-Maliki Press.

Mahyuni. (2004). Indirectness pada masyarakat Sasak: Fenomena metafor. Linguistik Indonesia 22(1), 89-103.

Mahyuni. (2007). Valuing language and culture: an example from Sasak. Jurnal Makara, Sosial Humaniora 11(2), 79-86.

Saharudin. (2014). Refleksi kohesivitas sosial penutur bahasa Sasak dan kecenderungannya bertransformasi. Makara Hubs-Asia 18(2), 140-148.

Smith, B.J. (2014). Stealing women, stealing men: Co-creating cultures of polygamy in a pesantren community in eastern Indonesia. Journal of International Women's Studies 15(1), 118-135.

Soekanto, S. (2005). Sosiologi suatu pengantar. Jakarta: Rajawali Pers.

Yasin, M.N. (2008). Hukum perkawinan Islam Sasak. Malang: UIN-Maliki Press.

Zuhdi, M.H. (2012). Praktik merariq: Wajah sosial masyarakat Sasak. Mataram: LEPPIM IAIN Mataram. 